\title{
Community Participation and Rural Development in Bushenyi District, Western Uganda
}

\author{
Mbyemeire Patrick \\ Kampala international University \\ E-mail: patrick.kyangabo@gmail.com \\ Byabashaija Deusdedit (Corresponding author) \\ Kampala international University \\ Western Campus, P.O. Box 71, Bushenyi, Uganda
}

Tel: 256-774-525-307 E-mail: dbyabashaija@gmail.com

\author{
Tumwesigye Mathias \\ Kampala international University \\ E-mail: tumwesigye.mathias@kiu.ac.ug \\ Mbabazi Lawrence \\ Kampala international University \\ E-mail: mbabazilawrence@gmail.com
}

Kahara M. Amos

Kampala international University

E-mail: kahara100@yahoo.com

Afikwu-Abba C. Abodaya

Kampala international University

E-mail: afikwu-abba@gmail.com 
Received: May 20, 2016 Accepted: June 24, 2016 Published: September 20, 2016

doi:10.5296/jad.v2i2.10041 URL: http://dx.doi.org/10.5296/jad.v2i2.10041

\begin{abstract}
This article assessed the correlation between community participation and rural development in Bushenyi District. Utilizing survey cross sectional research design, a close ended questionnaire and an interview schedule were used to collect information which was utilized to respond to the research questions on how community participation relates to rural development in Bushenyi District in Western Uganda. Data was analyzed employing descriptive statistics like frequencies, percentages, tables and bar graphs. The researcher used Pearson linear correlation coefficient to establish the relationship between the variables under study. The study revealed that there was a significant positive and strong relationship between community participation and rural development in Bushenyi District. The researcher recommends that there is need to empower local council committees to be able to make decisions that are tailored to their local circumstances that can always steer up development. The government in Uganda should augment on the conditional and unconditional grants to local governments in order to help local government officials mobilize and sensitize the populace for self reliance and self help projects.
\end{abstract}

Keywords: Community participation, Rural development, Management, Uganda 


\section{Introduction}

The practice of rural development has been in focus for a long time by many development practitioners and is by now widely cited in national and international policy documents (Koutsouris, 2008). The development process in rural areas is based on different conditions. The process of rural development is a participatory set of activities that involves local people, its natural environment, outside development practitioners and other stakeholders including development agencies (Chambers \& Conway, 1991). The process of rural development evolves a multidisciplinary set of practices through a series of time. During this process, these sets of development practices generate different forms of knowledge. This composition of knowledge is formed by combining local areas, indigenous knowledge and outside world knowledge experience that comes through the development actors (Hess, 2006). The purpose of this study was to establish the relationship between community participation and rural development in Bushenyi District, Western Uganda.

\section{Literature Review}

The concept of community participation has become one of the most important subject matters discussed in various disciplines that needs human input in the development process. In general, the concept of participation in this literature has been used to describe many kinds of activities and processes carried out, directive or non directive by the authorities responsible, or initiated by people themselves to bring social development and improvement for the betterment of community members.

Oakley and Marsden (1984) in their attempt to define this concept have outlined a continuum of definition based on different interpretations ranging from defining participation merely as a means at one end of the continuum, towards describing it as a process with some element of peoples' control at the other end. As a means, participation is considered as; " a voluntary contribution by the people in one way or another to public programs supposed to contribute to national development but the people are not expected to take part in shaping the program or criticizing its content" (Oakley \& Marsden, 1984). On the other hand, participation can be defined as a process in itself where people have some control over the whole development process (Oakley \& Marsden, 1984).

Rural development is any effort aimed at improving and/or enhancing rural livelihoods in the social and economic domains. It involves both the transformation of lives and landscape to ensure a significant improvement in the quality of life of the rural folk. Thorbecke (1992), contends that 'the rural poor people, who represent a latent productive potential, need to be provided with an appropriate policy and institutional framework, resource and technology support, and an enabling market environment so that they can raise their productivity on land where access to it is assured, and raise their income through off-farm income generating activities, where there is a scope for generation of productive employment'. There can be no other way of achieving this other than preparing the rural people with the necessary skills that would permit them to explore other avenues and other activities. Moreover, the success of this scenario lies in the fact that dialogue is created with those who will be directly or indirectly affected by any decisions and actions. Implicitly, decisions and responsibilities 
should be shared instead of imposing on the people because Mikkelsen (2005) argues that participation is not only a democratic principle, it is a right.

\section{Methods}

\subsection{Data Collection}

The sample size was arrived at using slovens's formula. Both primary and secondary sources were employed .Primary data was reached at by use of structured questionnaires distributed to 200 participants out of 400 target population. Interviews were conducted to important people associated to the research study. Secondary data was obtained through use of documentary reviews. A descriptive research design was employed involving qualitative and quantitative approaches in order to have a narration of the environment of the research. There were 128 males (64\%) and 72 females (36\%).

\subsection{Sampling Strategies}

Stratified and purposive sampling techniques were used by the researcher. The target population comprised of the categories like civil servants (20), the civil society organizations (35), councilors (20), Political leaders (68), Youth leaders (43), women (80), people with disabilities (10), Nongovernmental organizations (44), and Community based organizations (80). Total number of the target population leading to 400 people.

\subsection{Validity and Reliability of Instrument}

The close ended questionnaire's validity was assured by employing content validity Index. The researcher obtained content validity index (CVI) of 0.77 which was well above 0.75 showing that the instrument was valid to elicit the data for the research study (Amin, 2005). However, the validity of the open ended interviews was obtained by interviewing key participants to validate the answers in the structured questionnaires (Gibbs, 2007).

The Structured Questionnaire's reliability was calculated using Cronbach's alpha coefficient formula .Since the calculation of the reliability reached at by the researcher gave 0.78 alpha value greater than 0.70 , it implied that the research instrument was reliable to collect data required for the research study. However, the reliability of the close ended interview was got by resorting to peer review guidelines (Gibbs, 2007).

\subsection{Data Analysis}

Data was analyzed using descriptive statistics such as frequencies, percentages, Bar graphs and Pearson linear correlation coefficient regarding how community participation correlates to rural development in Bushenyi District, Western Uganda. Qualitative data were analyzed by scientifically organizing information into logical themes and sub themes for easy Interpretation along a storyline (Gibbs, 2007). 


\section{Results}

\subsection{Demographic Characteristics}

Figure 1 below presented the Gender characteristics of the respondents. It showed that male respondents were the majority constituting $128(64 \%)$ in the sample as compared to their female counterparts who were $72(36 \%)$ of the entire sample.This implied that the views of the respondents were from both genders and that males dominate in Bushenyi District.

Figure 1 below also depicted the age characteristics of the respondents; the results revealed that most of the respondents were in the age-group of 15-25 years comprising $72(36 \%)$ and were followed by those in the age-group of 26-36 years representing 64 (32\%) of the sample. The minority were in the age-group of 37-47 years and the 48-90 age-group constituting 28 $(14 \%)$ and $36(18 \%)$ respectively of the sample.This suggested that the majority of the respondents were in the age bracket which is still energetic to participate in community activities for development and therefore a good age bracket category to provide relevant information to the researcher.

Figure 1 below also depicted the marital status of the respondents. The figure shows that 16 $(8 \%)$ of the respondents are single, $100(50 \%)$ of the respondents were married while $24(12 \%)$ and $60(30 \%)$ of the respondents are widows and separated respectively. This result implied that the majority of the respondents were mature and stable in their families having a sound mind to provide good answers to the research questions.

Figure 1 below also indicated that $8(4 \%)$ of the respondents had not attained any level of education, 28(14\%) attended primary school, 52(26\%) attended secondary school and $112(56 \%)$ had attended tertiary institution. Since majority of the respondents had attended the tertiary institutions; the implication is that the respondents were well knowledgeable of the subject matter and as such they helped the researcher make informed decisions. 


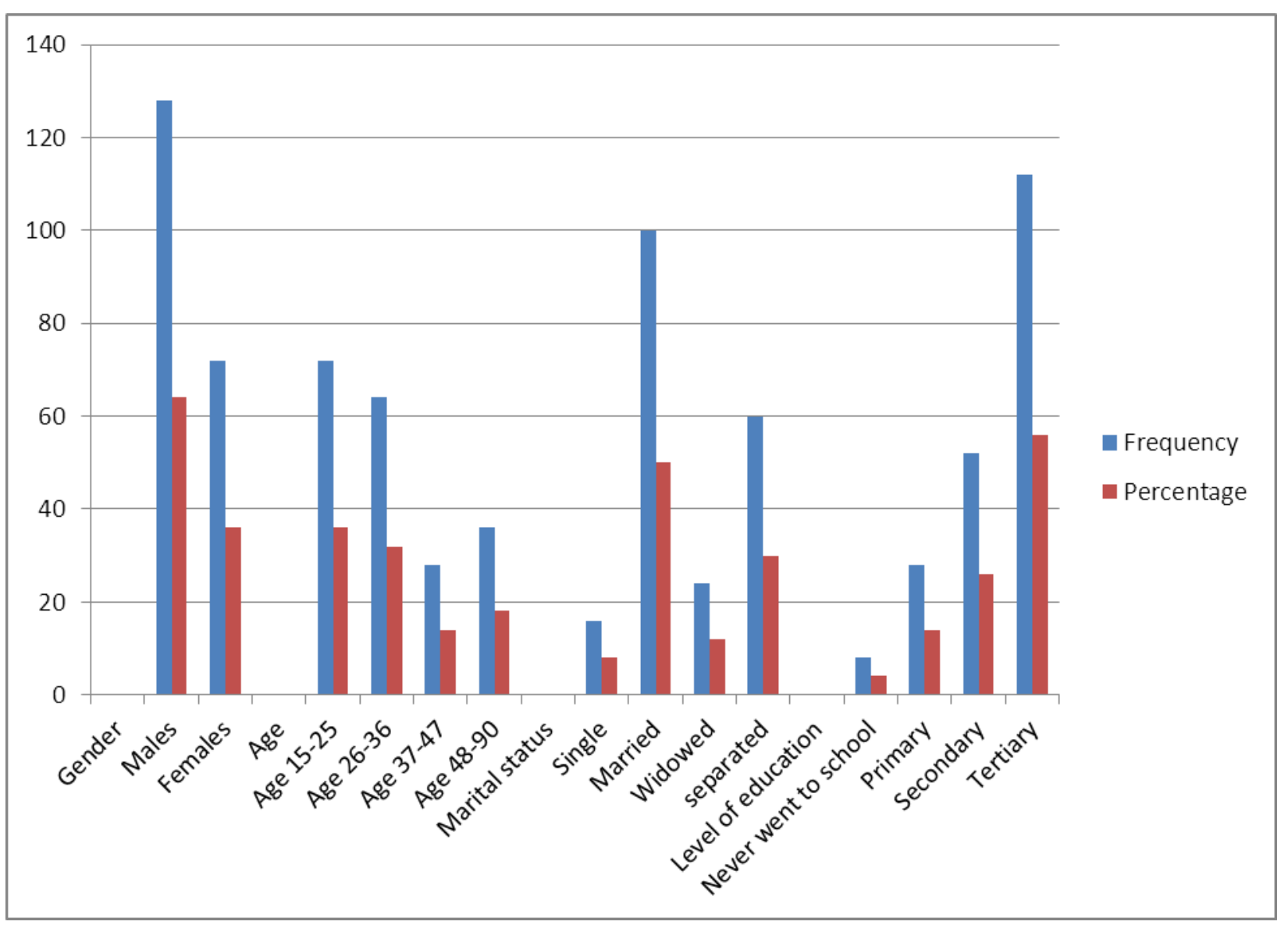

Figure 1. Bar graph showing Demographic characteristics of participants

Source: Primary data

4.2 Analysis of the Effectiveness of Community Participation in Rural Development in Bushenyi District

Table 1 below shows the responses to the Likert-scale question, the sample mean (x), and the sample standard deviation $(\delta)$ score. For the question on whether Community Participation in policy formulation results to rural development, the responses showed that $110(55.00 \%)$ of the respondents strongly agreed that Community Participation in policy formulation leads to rural development, 35 (17.50\%) agreed, 3 (1.50\%) were undecided, while $25(12.50 \%)$ and $27(13.50 \%)$ disagreed and Strongly disagreed respectively that Community Participation in policy formulation leads to rural development. The associated sample mean of the responses is 4.11with a sample standard deviation of 1.38. This suggested that, Community Participation in policy formulation leads to rural development; hence the mean is $\geq 3.5$. This meant that development must be pro people and guided by appropriate policies for rural transformation.

For the question on whether community participation in poverty alleviation programs increases well being of members of the community, the responses showed that, $90(45.00 \%)$ 
percent of the respondents strongly agreed that community participation in poverty alleviation programs increases well being of members of the community, $54(27.00 \%)$ of the respondents agreed, $6(3.00 \%)$ were undecided, while $30(15.00 \%)$ and $20(10.00 \%)$ disagreed and strongly disagreed respectively that community participation in poverty alleviation programs increases well being of members of the community. giving a sample mean of 4.01 and a sample standard deviation of 1.29. This suggested that, most of the respondents agreed that community participation in poverty alleviation programs increases well being of members of the community; hence the mean is $\geq 3.5$. This implied that poverty reduction needs the participation of all stake holders at different levels.

For the question on whether community participation in conjunction with Non governmental organizations, donor agencies and international organizations have led to rural development, the responses showed that, $105(52.50 \%)$ percent of the respondents strongly agreed that community participation in conjunction with NGOs, donor agencies and international organizations have led to rural development, $20(10.00 \%)$ of the respondents agreed, 5 $(2.50 \%)$ were undecided, while $45(22.50 \%)$ and $25(12.50 \%)$ disagreed and strongly disagreed respectively that community participation in conjunction with NGOs, donor agencies and international organizations has led to rural development, giving a sample mean of 3.98 and a sample standard deviation of 1.29. This meant that, most of the respondents agreed that community participation in conjunction with NGOs, donor agencies and international organizations has led to rural development; hence the mean is $\geq 3.5$. This implied that NGOS play a vital role in rural development.

For the question on whether community participation in development projects by designing programmes and controlling social and economic institutions may lead to rural development, the responses showed that, $80(40.00 \%)$ percent of the respondents strongly agreed that community participation in development projects by designing programmes and controlling social and economic institutions may lead to rural development, 70 (35.00\%) of the respondents agreed, $2(6.06 \%)$ were undecided, while $30(15.00 \%)$ and $18(9.00 \%)$ disagreed and strongly disagreed respectively that community participation in development projects by designing programmes and controlling social and economic institutions may lead to rural development. giving a sample mean of 4.04 and a sample standard deviation of 1.25. This suggested that, most of the respondents agreed that community participation in development projects by designing programmes and controlling social and economic institutions has led to rural development; hence the mean is $\geq 3.5$. This meant that social institutions are very important in Rural transformation.

For the question on whether community consultation and material incentive towards the community needs may lead to a meaningful development of the rural areas, the responses showed that, $99(49.50 \%)$ percent of the respondents strongly agreed that community consultation and material incentive towards the community needs may lead to a meaningful development of the rural areas $45(22.50 \%)$ of the respondents agreed, $6(3.00 \%)$ were undecided, while $15(7.50 \%)$ and $35(17.50 \%)$ disagreed and strongly disagreed respectively that community consultation and material incentive towards the community needs may lead to a meaningful development of the rural areas, giving a sample mean of 3.98 and a sample 
standard deviation of 1.35 . This meant that, the majority of the respondents agreed that community consultation and material incentives towards the community needs has led to a meaningful development of the rural areas; hence the mean is $\geq 3.5$. This implied that community participatory approaches should be given a priority in order to achieve rural community sustainable development.

Table 1. Descriptive Statistics on the Effectiveness of Community Participation on Rural Development

\begin{tabular}{l}
\hline \\
$\begin{array}{l}\text { Community Participation in policy formulation results } 110 \\
\text { to rural development }\end{array}$ \\
$\begin{array}{l}\text { Community participation in Poverty alleviation } \\
\text { 1. }\end{array}$
\end{tabular}

Source: Primary Data

Decision rule:

If mean $<3.0$ the respondents Disagree

If $3.0 \leq$ mean $\leq 3.5$ the respondents are Undecided

If mean $\geq 3.5$ the respondents Agree

\subsection{Relationship between Community Participation and Rural Development}

The correlations analysis was used to establish the relationships between the variables under study using the Pearson linear Correlation coefficient which measures linear association between the variables. It reflects the magnitude and direction of the relationship as shown in

Results from Table 2 below revealed that there was a significant positive and strong relationship between community participation and rural development $(\mathrm{R}=0.919, \mathrm{p}=0.00)$ in Bushenyi district local government in Western Uganda. The result is supported by the p-value 
(0.00) which is significant at $01 \%$ level of significance. This showed that if community participation is strengthened, then rural development will be enhanced. The finding is in consonant with the work of Nekwaya, (2007); Aref and Redzuan, (2009); Burkey, (1993); and Oakley (1991) who found out that community participation has a positive effect on rural development.

Table 2. Correlations

\begin{tabular}{llll}
\hline & & $\begin{array}{l}\text { Rural } \\
\text { Development }\end{array}$ & $\begin{array}{l}\text { Community } \\
\text { Participation }\end{array}$ \\
\hline Pearson Correlation & Rural Development & 1.000 & .919 \\
& Community Participation & .919 & 1.000 \\
Sig. (1-tailed) & Rural Development &. & .000 \\
& Community Participation & .000 &. \\
\hline
\end{tabular}

Source: Primary Data

\section{Discussion}

The study found out that community participation has a significant role in rural development; hence the overall mean of the likert scale type questions is 4.02 , indicating that the majority of the respondents agreed that all forms of community participation in rural activities such as construction of schools, repair of roads, poultry, piggery, and cattle rearing may lead to the development of rural areas. These findings concurred with Samad (2002) who asserted that community participation of rural areas' activities leads to rural development. However, the study showed that the participation of the participants was passive and pseudo in real development. This was due to corruption tendencies of the district leaders. What was very obvious from this study was that most of the participants said that the participation was passive in that they were simply a set of activities such as construction of schools, repair of roads, poultry, piggery, and cattle rearing to participate in but not actively involved in the identification of activities to be undertaken at district level. The findings are consistent with the view that rural development is possible where people are able to mobilize and manage forces and resources in the community by creating opportunities for democratic decision making, active participation and co-operation. This was in agreement with (Roux, 1995; Oakley \& Marsden, 1991; Esman, 1991; Lea \& Chaudhri, 1983; Maxwell \& Nsingo, 2008; Storey, 1991; Swanepoel, 1998) who said that effective participation in rural activities leads to rural development.

The findings revealed that there was a significant and positive relationship between community participation and rural development in Bushenyi District. This was in line with the view that rural development can be taken to be an outcome of community participation (Roux, 1995; Oakley \& Marsden, 1991; Esman, 1991; Lea \& Chaudhri, 1983; Maxwell \& Nsingo, 2008; Storey, 1991; Swanepoel, 1998; Nekwaya, 2007; Aref \& Redzuan, 2009; 
Burkey, 1993; Oakley 1991) that community participation has a positive effect on rural development.

\section{Limitations}

Extraneous Variables: personal biases and honesty of the respondents were beyond the researcher's control. The researcher therefore, requested the respondents to avoid being subjective while answering questionnaires, follow the methodology stages with caution and keen interest to accomplish the study in peace with every participant.

Retrieval Rate: Not all questionnaires that were distributed were retrieved because the respondents claimed to have had a lot of work schedules. This delayed the process of retrieval of questionnaires from the respondents. The researcher distributed 250 questionnaires, but 200 questionnaires were retrieved and only 50 questionnaires were not retrieved.

\section{Conclusion}

The central focus of this study was to empirically investigate community participation and rural development, with focus on Bushenyi District in western Uganda. The study was able to establish the tremendous importance of community participation on rural development. The findings are in consonance with the work of Nekwaya, (2007); Aref and Redzuan, (2009); Burkey, (1993); and Oakley (1991) who found out that community participation in all forms of community programmes such as poverty alleviation programmes, consultation, policy formulation and in conjunction with NGOs, donor agencies and international bodies involved in rural activities such as construction of schools, repair of roads, poultry, piggery, and cattle rearing lead to the development of the rural areas.

Therefore, the strong and positive relationship of community participation and rural development shows that, community participation is taken to be the "software" in rural development. Community participation as a development approach is essential in the wheel of ensuring that community projects and programmes are well executed, monitored, managed, evaluated, maintained, financed and sustained for the benefit of the present generation and posterity of Bushenyi District. Developing skills of the individuals in a given society may enhance the quality and quantity of the output of social capital through collective actions and decisions. From the findings of this study it is therefore highly imperative to recommend that a "demand-driven" strategy that has the merit of considering the specific demands and the needs of the citizenry should be implemented.

Hence, the local government institutions and local community organizations should establish a collaborative partnership in undertaking the responsibility for developing a local vision, mission and strategy in general planning, allocating resources, implementing, monitoring and evaluation of development activities that would best cater for the local needs for rural development. This may encourage a joint driving force towards development, develop a "sense of shared ownership" and become "managers" of their development initiatives. 


\section{Macrothink}

Journal of Asian Development

ISSN 2377-9594

2016, Vol. 2, No. 2

\section{References}

Aref, F. \& Redzuan, M. (2009). Assessing the Level of Community Participation as a Component of Community Capacity Building for Tourism Development. Journal of Scientific Research, 28, 443-450.

Burkey, S. (1993). People First: A Guide to Self Reliant, Participatory Rural Development. London: Zed Books.

Chambers, S., \& Conway,R. (1991). Rural Development: Principles and Practice. London: Sage Publications.

Esman, M. J. (1991). Managing Dimesion of Development Development. Perspective and Strategies. Connecticut: Kumarian Press.

Gibbs, G. (2007). Analysing Qualitative Data. University of Warwick, London.

Hess, L. J. (2006). Outcome Evaluation Criteria used in Public Participation Evaluation Studies. Canadian Policy Research Network, 29(4), 512-556.

Lea, A. M., \& Chaudhri, D. P. (1983). Rural Development and the State. New York: Methuen $\&$ Co. Ltd.

Maxwell \& Nsingo, S. (2008). Citizen Participation in Local Government and the Process of Rural Development: The Rhetoric and Reality of Uganda. Journal of Public Administration, 43, 107-123.

Mikkelsen, A. I. (2005). Is Increasing Community Participation Always a Good thing? Harvard University Journal, Vol. 344(4), 357-338.

Nekwaya, J. H. (2007). Assessing Community Participation in Development Planning and Service Delivery. A case study of the Omusati Regional Council (Master of Sustainable Development and management: University of Stellenbosch).

Oakley, P. \& Marsden, D. (1984). Approaches to Participation in Rural Development. Geneva: International Labour Office Publications.

Oakley, P., \& Marsden, D. (1991). Project with People: The Practice of Participation in Rural Development. Geneva: International Labour Office Publications.

Roux, M. (1995). New Dictionary of Social Work. Department of Social Work. Cape Town: CTP Book Printers (Pty) Ltd.

Samad, M. (2002). A Framework of Participation in Community Organization. Journal of Applied Behavioural Science, 17(1), 27-58.

Storey, D. (1991). Issues of Integration, Participation and Empowerment in Rural Development: Case of Leader in the Republic of Ireland. Journal of Rural Studies, 15(3), 307-315.

Swanepoel, H. (1998). Community Development: Breaking the Circle of Poverty (4th ed.). 
Johannesburg: Juta \& Co.

Theobecke, E. (1992). Rural Indonesia: Socio-Economic Development in a Changing Environment. London: New York Press.

\section{Copyright Disclaimer}

Copyright reserved by the authors.

This article is an open-access article distributed under the terms and conditions of the Creative Commons Attribution license (http://creativecommons.org/licenses/by/3.0/). 